Studia Anglica Posnaniensia 45/2, 2009

doi: 10.2478/v10121-009-0021-6

\title{
THE PLEASURE OF THE EIGHTEENTH-CENTURY TEXTS: THE CONFLATION OF LITERARY AND CRITICAL DISCOURSE IN THE EARLY NOVELISTIC TRADITION
}

\author{
JOANNA MACIULEWICZ
}

Adam Mickiewicz University, Poznań

\begin{abstract}
One of the prominent characteristics of contemporary literature is its assimilation to critical discourse. The self-reflexivity in literature, which transforms literary texts into acts of criticism, is paralleled by theory's tendency to encroach on the literary domain. One of the findings of the poststructuralist literary theory is that descriptions of reading experience elude scientific language and are more aptly conveyed by metaphors. (A good example is Roland Barthes' The pleasure of the text.) The conflation of literary and critical discourse is not, however, peculiar to postmodernity only. The same phenomenon is observable in the eighteenth-century writings. It turns out that the self-reflexivity evident at the times of the proclaimed "death of the novel" is manifest also in the times of its birth. The aim of my paper is to analyse the metafictional reflection on readerly pleasure incorporated in early novelistic texts.
\end{abstract}

The publication of Roland Barthes' The pleasure of the text (1975) is one of the crucial points in the history of criticism since it demonstrates that the description of the process of reading eludes all scientific descriptions. Barthes rediscovers the truth that had been emphasised by traditional critics before him but has been understated by the twentieth-century critics, perhaps as too obvious to be talked about. The quintessential quality of literature, as well as its most effective weapon, is its capability of providing pleasure, and pleasure does not lend itself to precise explanations. "It is not enough for poetry to be beautiful", says Horace in Ars Poetica, "it must also be pleasing and lead the hearer's mind wherever it will" (1989: 100). Sidney repeats the opinion in his Apology of poetry. "Now therein of all sciences ... is our poet the monarch. ... he comes to you with words set in delightful proportion ... with a tale which holdeth children from play and old men 
from chimney corners" (Sidney 2001: 340-341). Barthes' publication demonstrates that in order to talk about what "holdeth children from play and old men from chimney corners" the literal, tangible language of linguistics, the language of signifiers and signifieds, employed by the structuralists with a view to provide the scientific analysis of literary discourse, will not do. He renounces it in favour of the figurative and tantalising language used by literature itself. "The text you write must prove to me that it desires me. This proof exists, it is writing. Writing is: the science of the various blisses of language, its Kama Sutra (this science has only one treatise: writing itself)" (Barthes 1975: 6). The aim of texts, Barthes argues, is "the seduction of their readers" and from this point of view they can be categorised as "flirtatious" or "frigid".

It would seem that eighteenth-century fiction did not associate its own values with pleasure, that they were frigid rather than flirtatious, if we were to use Barthes' terminology. After all, it was produced in the Puritan times and not in the permissive conteporaneity. The eighteenth-century literati apparently subscribed to Horace's opinion that literature should in equal degree instruct and delight but in fact, as Paul Hunter argues, "English writers regularly saw their public function in more utilitarian terms than a strict reading of Roman literary theory would support, and the Horatian ideal usually meant an attempt to make instruction palatable, as delightful as possible within the understood - but seldom directly stated - assumption that instruction was the only appropriate end" (1990: 240). Puritan culture, lasting according to Hunter, from the Civil War to mid-eighteenth century, could not create a conducive climate for the flourishing of pleasure. (Jeanette Winterson's character from Sexing the cherry describes Puritans as walking with "their starched linen to their noses for fear they might smell pleasure and be infected by it" (Winterson 1990: 26-27). In such a context, Hunter asserts, delight is "either means or by-product rather than an end in itself" and although "[i]t is easy to exaggerate the tilt toward instruction in those times because the bias in ours is so strong toward delight", it is hard to overlook the "imbalance", which was "virtually the mirror image of ours", and which was particularly "extreme" (1990: 240) in prose works.

Clara Reeve, for one example, the author of one of the earliest histories of the novel, reveals the society's preoccupation with the influence of the novel on the reading public. The full title of her work is The progress of romance through times, countries, manners; with remarks on the good and bad effects of $i t$, on them respectively... and it already stresses the aims of the analysis: the description of the development of the genre and its effect on the readers. Euphrasia, Reeve's mouthpiece, complains about the wrong books that young people are exposed to and proposes a scheme that would employ pleasure in the service of virtue: "I would select such books as were proper to be put into the hands of youth; and with the same circumspection I would carry them to the 
Theatres, to satisfy the curiosity of youth, and prevent their taking these amusements clandestinely, for how in an age like this could I prevent them?" (Reeve 1930: 84). And yet, despite the heavy didacticism of eighteenth-century literature, the subject of reading pleasure, coupled though it was to moral questions, received a lot of attention from the novelists, who tried to explore it, its sources and power to control it, either in paratextual material or by the incorporation of the theme into the plots of their narratives.

Lennard Davis (1996: 61) in his Factual fictions [1983] offers an interesting theory explaining the duality of didacticism and pleasure in the eighteenthcentury novel. According to him, the explanation lies in the novel's origin in "news/novels discourse", in which there exists a temporal proximity between the reader and the reported event. The diminishment of the time distance between the time of being and time of telling creates an illusion that the readers are observing the recounted facts themselves. He explains:

\begin{abstract}
Given the assumptions of the news/novels discourse, journalism demands that the reader be actively or passively part of the ongoing story, since newspapers tell the story of the daily world in which the observer lives. In this sense, the reader's functions are split in a way I would think is unique to this discourse - that is, the reader is at once subject and object. The effect of this duality is that ballads [which are treated as antecedents of the novel] can preach at readers to obey various religious and moral precepts and at the same time permit those same readers to voyeuristically watch these transgressions as they are described
\end{abstract}

(Davis 1996: 61).

The readerly pleasure thus, according to Davis' theory, stems from the voyeuristic pleasure of observing the forbidden deeds which often found way to the news/novel discourse.

The best illustration of the duality of purpose bequeathed by the ballads to the early novelistic narratives can be found in Daniel Defoe's fiction, which thrives on sensational themes. In Moll Flanders [1722], to take the most famous example, all transgressions against society are neatly summarised and announced in the famous title: The fortunes and misfortunes of the famous Moll Flanders \& c. who was born in Newgate, and during a life of continu'd variety for threescore years, besides her childhood, was twelve years a whore, five times a wife (whereof once to her own brother), twelve years a thief, eight years a transported felon in Virginia, at last grew rich, liv'd honest, and dies a penitent. Written from her own memorandums... In the preface to the novel the putative editor draws attention to the double-edged power of the novel claiming that it is his task to avert the danger of attracting readers searching for lewd material. He explains: "When a woman debauched from her youth comes to give an account of all her vicious practices ... an author must be hard put to it to wrap it up so clean as not to give room, especially for vicious readers, to turn it to his 
disadvantage" (Defoe 1994: 1). The author, however, realises that, despite all the efforts he makes to lead the readers safely to the moral lesson, the attraction of the story lies in the "wicked" part of the narrative, which can produce an effect contrary to the one intended. The account of Moll's crimes is included to set off her repentance, but they may merely provide readers pleasure of vicarious participation in the immoral deeds since the process of reading in general, and pleasure stemming from it in particular, can hardly be controlled.

It is suggested there cannot be the same life, the same brightness and beauty, in
relating the penitent part as in the criminal part. If there is any truth in that sugges-
tion, I must be allowed to say, 'tis because there is not the same taste and relish in
the reading, and indeed it is too true that the difference lies not in the real worth
of the subject so much as in the gust and palate of the reader

(Defoe 1994: 2, emphasis mine).

Defoe's fiction exploits the readers' fascination with social taboos, smuggling the forbidden subjects into the plots of the narratives under the guise of moral preaching by giving negative examples to be avoided.

The readerly pleasure, however, was not necessarily bound with the desire to observe the transgressions of virtue. The life stories of virtuous personas had an equally rich potential to provide readerly pleasure, which manifested itself in the great popularity of factual and fictional spiritual autobiographies. The chief attraction of this kind of writing was its introspective nature, which afforded a glimpse into the most intimate aspects of human experience. Yet, if initially the interest in the intimate details of other people's lives stemmed from the religious motivation of searching models of perfection, it became soon secularised, which can be exemplified by An apology for the life of Colley Cibber published in 1740. This text, as Hunter claims, for "observers like Pope and Henry Fielding" was an act of "an exhibitionist, an egomaniac, and a fool, but novelists in fact had to face, for similar reasons, similar charges from the beginning, and their only defence ultimately was that the selves they exhibited, and celebrated, were not fully their own" (1990: 229-230). And thus already in 1749, Henry Fielding in Tom Jones [1749] (Book VIII, chapter one) specifies the area of interest of the novel, and claims that novelists are "confined" to "scenes of private life" and "search into the most retired recesses and draw forth the examples of virtue and vice from holes and corners of the world" (1994: 338). Thus, they give rise to the long association of the novel with individual experience (Watt 1993: 14).

Paradoxically, the disclosure of the intimacy of the human mind could also prove a double-edged weapon in the eternal struggle for virtue. The reception of Pamela, or Clarissa, by Samuel Richardson is a good case in point. Richardson in this text employs "writing-to-the-moment" technique, which is the maximum 
diminishment of temporal distance between the events and their transcription. In fact the proximity is so exact that on numerous occasions Pamela has to switch to present tense to report them. The very proximity, however, induced mixed responses from the readers. Although the tale was told to reveal the inner workings of a virtuous mind, some readers seem to have derived some perverse pleasure from such close observation of Pamela's defence against the sexual attacks of her persecutor. As Lennard Davis explains, it is exactly the publication of what is private that provides the readerly pleasure and thus the question of virtue is lost from sight.

\begin{abstract}
That movement [toward the notion of the publication of experience] also leads toward a kind of eroticisation of the text. Richardson's work demands that the reader continually be the voyeur, placed in much the same position as Lovelace or Mr. B. in intercepting the letters of the heroines and penetrating their discourse. The experience of reading Pamela or Clarissa is the experience of staring through the keyhole along with the kidnappers. Bared bosoms, stolen kisses, and supine, helpless figures are the essence of Richardson's eroticism, and the reader of the work is placed within the text as voyeur much as readers of the news/novels discourse
\end{abstract}

(Davis 1996: 187-188).

The critic concludes that "[v]oyeurism is one of the preconditions of the novel, and it is also the essence of the private world-made-public, which is to say, voyeurism is inherent in the news/novels discourse" (1996: 188-189).

While such a reception of Richardson's moralising fiction may not seem surprising in our own times, which are wont to search for sexual undertones in all sorts of texts, Davis assures that this kind of reading was not rare at the time of its original publication. It seems that the eighteenth-century writers, Richardson and his critics alike, were aware of the pleasure that their readers derived from the perusal of characters' intimate confessions. Henry Fielding, for one instance, ridicules both the effect of temporal proximity between the time of happening and time of telling the events as well as the willingness to divulge the private details of life in one of the most famous scenes of Shamela [1741].

Mrs. Jervis and I are just in Bed, and the Door unlocked; if my Master should come-Odsbobs! I hear him just coming in at the Door. You see I write in the present Tense, as Parson Williams says. Well he is in Bed between us, we both shamming a Sleep, he steals his Hand in my Bosom, which I, as if in my Sleep, press close to me with mine, and then pretend to awake.--I no sooner see him, but I scream to Mrs. Jervis, she feigns likewise but just to come to herself; we both begin, she to becall, and I to bescratch very liberally. After having made a pretty free Use of my Fingers, without any great Regard to the Parts I attack'd, I counterfeit a Swoon

(Fielding 1999: 318). 
The same awareness of the pleasures gained from observing someone else's private life is matafictionally thematised in the plot of Pamela itself. It seems that Mr. B is as much the lover of Pamela's person as her diary and his family shows the same passion for her writing when they have learnt the story of the couple's peculiar courtship. Davis points to the language of desire employed by characters when they talk about Pamela's manuscript. "[Mr. B] frequently expresses his readerly devotion with such comments as 'I long to see the particulars of your plot ... and am desirous of reading all you write'. Lady Davers also expresses her excitation about Pamela's transcription of the story '.. I understand child, says she, that you keep a journal of all matters that pass ... I should delight to read all of his [Mr. B's] stratagems, attempts, contrivances, menaces, and offers to you' (quoted in Davis 1996: 184). The desire and the delight, which Mr. B and Lady Davers confess, hardly convey an impression of being derived from the joy in the triumph of virtue. These remarks as well as the association of the themes of the seduction of the body with the seduction by the text lead to two conclusions. Firstly, the dramatisation of the constant warfare between virtue and $\sin$ in the heavily didactic eighteenth-century novel afforded a lot of opportunities to cater to the readers' less edified and spiritual tastes. Secondly, the novels demonstrated quite a high awareness of what could really seduce readers into reading.

Surprisingly enough, the metafictional divagations about the reading pleasures that are included in the eighteenth-century novels are frequently dressed in erotic metaphors, comparable to those employed by Roland Barthes. Yet, for Barthes this is the only way of talking about literature:

How can we take pleasure in a reported pleasure (boredom of all narratives of
dreams, of parties)? How can we read criticism? Only one way: since I am here a
second-degree reader, I must shift my position: instead of agreeing to be the con-
fidant of this critical pleasure - a sure way to miss it - I can make myself its vo-
yeur: I observe clandestinely the pleasure of others, I enter perversion; the com-
mentary then becomes in my eyes a text, a fiction, a fissured envelope

(Barthes 1975: 17).

William Warner describes in his study one of the most explicit as well as selfconscious cases of the conflation of reading and erotic pleasure. It is to be found in one of the inset stories of Maria Delarivier Manley's New Atalantis [1709]. The plot of the narrative seems to dramatise all the problems discussed by the critics of the novel: it demonstrates the power of fiction to edify or, reversely, to corrupt young minds. Thus, the readerly pleasure becomes closest to Barthes' understanding of critical voyeurism since it stems from the observation of someone else's readerly pleasure, and the pleasure is strongly associated with sexual pleasures. Young Charlotte brought up by a duke is prepared for life in 
the world by the reading assigned to her by her guardian, who first endeavours to instil virtue, and then, upon falling in love with her, also by means of selection of reading matter, inflames all the dangerous passions in her with a view to seduce his young ward. In Manley's narrative reading and sex converge. As, Warner observes, "[n]ovel reading achieves the effects of touching at a distance, it becomes touching by other means" and the scene of Charlotte's all-night reading is presented as an orgy of reading, where "reading about sex ... is here represented as sex" (1998: 108).

By detouring the representation of social vices into the form of novels, and by making those novels sexy and absorptive, two kinds of bodies are engaged - the explicitly sexualised bodies of the novel's protagonists, and the bodies of the novel readers. ... Manley intrigues her reader with a narrative which is structured to seduce the reading body into pleasure. It is this tendency of the novels of amorous intrigue that makes them a scandal in early-eighteenth century England

(Warner 1998: 99).

Manley's novel in the most self-conscious way demonstrates the duality of the novelistic discourse, which on the one hand is to serve the purpose of moral instruction and on the other, is to attract readers. "Manley", as Warner concludes, "recuperates the antinovel discourse for a distinctly novelistic pleasure" (Warner 1998: 110). Criticism thus becomes but a mere pretext to "observe clandestinely the pleasure of others".

Given the fact that the origins of the novel coincide with the dominance of Puritan values, novelists of the period devote quite a lot of attention to the problem of readerly pleasure. They seem to be well aware of the fact that it is not only the triumph of virtue which readers will find attractive. Quite surprisingly, readerly pleasure as well as criticism as such, in the times where chastity was a high value, was described with the help of sexual metaphors or metonymies, which would stress the potential damage that fiction could make as well as the power of allurement it had for the reading public.

\section{REFERENCES}

Barthes, Roland

1975 The pleasure of the text. (Translated by Richard Miller.) New York: Hill and Wang. Defoe, Daniel

1994 Moll Flanders. London: Penguin Books.

Davis, Lennard

1996 Factual fictions. The origins of the English novel. Philadelphia: University of Pennsylvania Press. 
Fielding, Henry

1994 Tom Jones. London: Penguin Books.

Fielding, Henry

1999 Joseph Andrews. Shamela. Oxford: Oxford World's Classics.

Horace

"The Art of Poetry" (translated by D. A. Russell), in: D. A. Russell - Michael Winterbottom (eds.), 98-110.

Hunter, Paul

1989 Before novels. The cultural contexts of eighteenth-century English fiction. New York - London: W. W. Norton and Company.

Leitch, Vincent B. (ed.)

2001 The Norton anthology of theory and criticism. New York - London: W. W. Norton and Company.

Reeve, Clara

1930 The progress of romance. New York: The Facsimile Socity.

Russell, D. A. - Michael Winterbottom (eds.).

1989 Classical literary criticism. Oxford: Oxford University Press.

Sidney, Sir Philip

2001 “An apology for poetry”, in: Vincent B. Leitch. (ed.), 326-362.

Warner, William

1998 Licensing pleasure. The elevation of novel reading in Britain, 1684-1750. Berkeley Los Angeles - London: University of California Press.

Watt, Ian

1993 The rise of the novel. Studies in Defoe, Richardson and Fielding. London: Hogarth Press.

Winterson, Jeanette

1990 Sexing the cherry. London: Vintage. 